\title{
Synthesis of $\left[\left\{\mathrm{AgO}_{2} \mathrm{CCH}_{2} \mathrm{OMe}\left(\mathrm{PPh}_{3}\right)\right\}_{n}\right]$ and theoretical study of its use in focused electron beam induced deposition
}

\author{
Jelena Tamuliene ${ }^{* 1, \S}$, Julian Noll ${ }^{2}$, Peter Frenzel ${ }^{2}$, Tobias Rüffer ${ }^{2}$, Alexander Jakob², \\ Bernhard Walfort ${ }^{2}$ and Heinrich Lang ${ }^{*} 2, \pi$
}

Open Access

\author{
Full Research Paper \\ Address: \\ ${ }^{1}$ Vilnius University, Institute of Theoretical Physics and Astronomy, \\ Sauletekio av. 3, Vilnius, Lithuania and ${ }^{2}$ Faculty of Natural Sciences, \\ Institute of Chemistry, Inorganic Chemistry, D-09107 Chemnitz, \\ Germany \\ Email: \\ Jelena Tamuliene* - Jelena.Tamuliene@tfai.vu.It; Heinrich Lang* - \\ heinrich.lang@chemie.tu-chemnitz.de \\ * Corresponding author \\ § Phone +370 5-223-34644; Fax +370 5-2125361 \\ II Phone +49 371-531-21210; Fax +49 371-531-21219 \\ Keywords: \\ DFT; DSC; FEBID; silver(I) carboxylate; solid-state structure; TGA
}

Beilstein J. Nanotechnol. 2017, 8, 2615-2624. doi:10.3762/bjnano.8.262

Received: 01 June 2017

Accepted: 15 November 2017

Published: 06 December 2017

This article is part of the Thematic Series "Chemistry for electron-induced nanofabrication".

Guest Editor: P. Swiderek

(C) 2017 Tamuliene et al.; licensee Beilstein-Institut.

License and terms: see end of document.

\begin{abstract}
The synthesis, chemical and physical properties of $\left[\left\{\mathrm{AgO}_{2} \mathrm{CCH}_{2} \mathrm{OMe}\right\}_{n}\right](\mathbf{1})$ and $\left[\left\{\mathrm{AgO}_{2} \mathrm{CCH}_{2} \mathrm{OMe}\left(\mathrm{PPh}_{3}\right)\right\}_{n}\right](\mathbf{2})$ are reported. Consecutive reaction of $\mathrm{AgNO}_{3}$ with $\mathrm{HO}_{2} \mathrm{CCH}_{2} \mathrm{OMe}$ gave 1, which upon treatment with $\mathrm{PPh}_{3}$ produced 2. Coordination compound 2 forms a 1D coordination polymer in the solid state as evidenced by single crystal X-ray structure analysis. The coordination geometry at $\mathrm{Ag}^{+}$is of the $[3+1]$ type, whereby the carboxylate anions act as bridging ligands. The formation of $\mathrm{PPh}_{3}-\mathrm{Ag}(\mathrm{I})$ coordinative bonds results in distorted T-shaped $\mathrm{AgPO}_{2}$ units, which are stabilized further by an additional $\mathrm{O}-\mathrm{Ag}$ dative bond. TG and TG-MS measurements show that 1 and 2 decompose at $190-250{ }^{\circ} \mathrm{C}(\mathbf{1})$ and $260-300{ }^{\circ} \mathrm{C}(\mathbf{2})$ via decarboxylation, involving Ag-P (2), $\mathrm{C}-\mathrm{C}$ and $\mathrm{C}-\mathrm{O}$ bond cleavages to give elemental silver as confirmed by PXRD studies. In order to verify if polymeric 2 is suitable as a FEBID precursor for silver deposition, its vapor pressure was determined $\left(p_{170}{ }^{\circ} \mathrm{C}=5.318 \mathrm{mbar}\right.$, $\left.\Delta H_{\text {vap }}=126.1 \mathrm{~kJ} \mathrm{~mol}^{-1}\right)$, evincing little volatility. Also EI and ESI mass spectrometric studies were carried out. The dissociation of the silver(I) compound 2 under typical electron-driven FEBID conditions was studied by DFT (B3LYP) calculations on monomeric $\left[\mathrm{AgO}_{2} \mathrm{CCH}_{2} \mathrm{OMe}\left(\mathrm{PPh}_{3}\right)\right]$. At an energy of the secondary electrons up to $0.8 \mathrm{eV}$ elimination of $\mathrm{PPh}_{3}$ occurs, giving $\mathrm{Ag}^{+}$and $\mathrm{O}_{2} \mathrm{CCH}_{2} \mathrm{OMe}^{-}$. Likewise, by release of $\mathrm{PPh}_{3}$ from $\left[\mathrm{AgO}_{2} \mathrm{CCH}_{2} \mathrm{OMe}\left(\mathrm{PPh}_{3}\right)\right]$ the fragment $\left[\mathrm{AgO}_{2} \mathrm{CCH}_{2} \mathrm{OMe}\right]^{-}$is formed from which $\mathrm{Ag}^{+}$and $\mathrm{O}_{2} \mathrm{CCH}_{2} \mathrm{OMe}^{-}$is generated, further following the first fragmentation route. However, at $1.3 \mathrm{eV}$ the initial step is decarboxylation giving $\left[\mathrm{AgCH} \mathrm{H}_{2} \mathrm{OMe}\left(\mathrm{PPh}_{3}\right)\right]$, followed by $\mathrm{Ag}-\mathrm{P}$ and $\mathrm{Ag}-\mathrm{C}$ bond cleavages.
\end{abstract}




\section{Introduction}

Focused electron beam induced deposition (FEBID) is a cost efficient direct resist-free chemical vapor deposition technique producing free-standing 3D metal-containing nanoscale structures in a single step on, for example, surfaces of sub-10 nm size using a variety of materials with a high degree of spatial and time-domain control [1-3]. Up to now, FEBID relies on the chemical availability of chemical vapor deposition (CVD) precursors. However, such precursors are not optimized for the electron-driven FEBID process and hence molecular precursors particularly adapted to its underlying electron-induced fragmentation mechanisms are needed.

Commonly, a FEBID precursor should display a high vapor pressure at reasonable temperatures and must have a satisfactorily long residence time on the surface typically lasting microto milliseconds, otherwise the corresponding layer thickness will be too small [4]. The respective volatiles, as result from dissociation, should be quickly removed to avoid their entrapment in the respective deposit. Therefore, precursors must be designed, which completely decompose under typical FEBID conditions. Recently, Botman et al. highlighted the difficulty in the deposition of pure metals [5]. In this context, the deposition of, for example, silver is challenging, since there is a lack of volatile silver precursors for FEBID processes [5]. Silver (nano)structures are of importance, for example, in circuits, batteries, LED or RFID chips, medicine and photovoltaics [1].

Recently, it was shown that coordination compounds, for example, silver(I) carboxylates can successfully be applied as singlesource species for silver nanoparticle formation [6] and as gasphase precursors in the deposition of pure, dense and conformal thin silver films [7-9].

This study aims for showing if $\left[\left\{\mathrm{AgO}_{2} \mathrm{CCH}_{2} \mathrm{OMe}\left(\mathrm{PPh}_{3}\right)\right\}_{n}\right]$ is a suitable FEBID precursor for silver deposition. Thus, we discuss the synthesis and the chemical and physical properties of $\left[\left\{\mathrm{AgO}_{2} \mathrm{CCH}_{2} \mathrm{OMe}\right\}_{n}\right]$ and $\left[\left\{\mathrm{AgO}_{2} \mathrm{CCH}_{2} \mathrm{OMe}\left(\mathrm{PPh}_{3}\right)\right\}_{n}\right]$. DFT (B3LYP) studies were applied to predict the most favorable fragmentation pathways according to the lowest energy of appearance for $\left[\mathrm{AgO}_{2} \mathrm{CCH}_{2} \mathrm{OMe}\left(\mathrm{PPh}_{3}\right)\right]$.

\section{Methods of Investigation Experimental}

The synthetic methodologies were performed under an atmosphere of argon with the solvents degassed prior to use. Ethanol (99\%) was distilled from sodium/diethyl phthalate, and acetonitrile ( $99 \%$ ) by distillation from sodium hydride and then from $\mathrm{P}_{2} \mathrm{O}_{5}$. Dichloromethane (95\%) and diethyl ether (99\%) were dried with a solvent purification system (MB SPS-800, MBraun). Silver(I) nitrate (99\%), methoxyacetic acid (97\%), triethylamine (99\%), triphenylphosphine (99\%) were obtained from commercial suppliers and used without further purification.

NMR spectra were recorded with a Bruker Advance III 500 spectrometer operating at $500.3 \mathrm{MHz}$ for ${ }^{1} \mathrm{H}, 125.7 \mathrm{MHz}$ for ${ }^{13} \mathrm{C}\left\{{ }^{1} \mathrm{H}\right\}$ and $101.3 \mathrm{MHz}$ for ${ }^{31} \mathrm{P}\left\{{ }^{1} \mathrm{H}\right\}$ in the Fourier transform mode at $298 \mathrm{~K}$. Chemical shifts are reported in $\delta(\mathrm{ppm})$ downfield from tetramethylsilane with the solvent as reference signal $\left({ }^{1} \mathrm{H} \mathrm{NMR}, \mathrm{CDCl}_{3} \delta=7.26 ;{ }^{13} \mathrm{C}\left\{{ }^{1} \mathrm{H}\right\} \mathrm{NMR}, \mathrm{CDCl}_{3}\right.$ $\delta=77.16 \mathrm{ppm})$ or by external standards $\left({ }^{31} \mathrm{P}\left\{{ }^{1} \mathrm{H}\right\}\right.$ NMR relative to $85 \% \mathrm{H}_{3} \mathrm{PO}_{4} 0.0 \mathrm{ppm}$ and $\left.\mathrm{P}(\mathrm{OMe})_{3} 139.0 \mathrm{ppm}\right)$.

The FTIR spectra were recorded using a Thermo Nicolet IR 200 instrument. Vapor pressure experiments were performed with a Mettler Toledo TGA/DSC1 1100 system with a UMX1 balance. The TG, DSC and TG-MS experiments were performed with a Mettler Toledo TGA/DSC1 1600 system with a MX1 balance coupled with a Pfeiffer Vacuum MS Thermostar GSD 301 T2 mass spectrometer. EI and high-resolution ESI mass spectra were recorded with a Finnigan MAT 8230 SQ instrument by using of ionization potential of $70 \mathrm{eV}$ (EI) and a Bruker Daltonik micrOTOF-QII mass spectrometer (Supporting Information File 1, Figures S1-S5).

Single crystal X-ray diffraction data of $\mathbf{2}$ were collected with an Bruker Smart CCD 1k diffractometer with Mo K $\alpha$ radiation $(\lambda=0.71073 \AA)$ at $298 \mathrm{~K}$. All structures were solved by direct methods using SHELXS-2013 and refined by full-matrix leastsquares procedures on $F^{2}$ using SHELXL-2013 [10]. All non-hydrogen atoms were refined anisotropically and all $C$-bonded hydrogen atoms were refined using a riding model. Graphics were created by using SHELXTL. Data have been deposited with the Cambridge Structural Database under CCDC 1552018 .

Synthesis of $\left[\left\{\mathbf{A g O}_{2} \mathrm{CCH}_{2} \mathrm{OMe}\right\}_{n}\right]$ (1) [11]. Silver(I) nitrate $(0.5 \mathrm{~g}(2.94 \mathrm{mmol}))$ was dissolved in a mixture of $20 \mathrm{~mL}$ of ethanol and $0.25 \mathrm{~mL}$ of acetonitrile at $25{ }^{\circ} \mathrm{C}$. To this solution a mixture of $0.26 \mathrm{~g}(2.89 \mathrm{mmol}, 0.22 \mathrm{~mL})$ of $\mathrm{HO}_{2} \mathrm{CCH}_{2} \mathrm{OMe}$ and $0.29 \mathrm{~g}(2.94 \mathrm{mmol}, 0.4 \mathrm{~mL})$ of $\mathrm{NEt}_{3}$ was dropwise added in between $5 \mathrm{~min}$. During the course of the reaction 1 precipitated as a colorless solid. After $2 \mathrm{~h}$ of stirring at ambient temperature the supernatant solution was decanted and the thus obtained solid was thoroughly washed with cold ethanol $\left(2 \times 20 \mathrm{~mL}\right.$ at $\left.0{ }^{\circ} \mathrm{C}\right)$ and diethyl ether $(2 \times 15 \mathrm{~mL})$. Yield: $0.53 \mathrm{~g}(2.69 \mathrm{mmol}, 91 \%$, based on $\mathrm{HO}_{2} \mathrm{CCH}_{2} \mathrm{OMe}$; silver content $55 \%$ ).

Anal. calcd for $\mathrm{C}_{3} \mathrm{H}_{5} \mathrm{AgO}_{3}: \mathrm{C}, 18.30 ; \mathrm{H}, 2.56 \%$; found: $\mathrm{C}$, 18.45, H, 2.63\%; mp $190{ }^{\circ} \mathrm{C}$ decomposition; IR $\left(\mathrm{KBr}, \mathrm{cm}^{-1}\right)$ v: 
$2999(\mathrm{~m}), 2835$ (m), $1610\left(\mathrm{CO}_{2, \text { asym }}, \mathrm{vs}\right), 1585$ (s), 1437 $\left(\mathrm{CO}_{2, \mathrm{sym}}, \mathrm{s}\right), 1430$ (s), 1332 (vs), 1206 (s), 1115 (vs), 990 (m), $932(\mathrm{w}), 769(\mathrm{~m})$.

Synthesis of $\left[\left\{\mathrm{AgO}_{2} \mathrm{CCH}_{2} \mathrm{OMe}\left(\mathrm{PPh}_{3}\right)\right\}_{n}\right]$ (2) [11]. Coordination compound $\mathbf{1}(0.53 \mathrm{~g}, 2.69 \mathrm{mmol})$ was dissolved in $30 \mathrm{~mL}$ of dichloromethane and $0.69 \mathrm{~g}(2.63 \mathrm{mmol})$ of $\mathrm{PPh}_{3}$ were added in a single portion at $0{ }^{\circ} \mathrm{C}$. The reaction solution was allowed to stir at ambient temperature for $2 \mathrm{~h}$. Afterwards it was filtered through a pad of Celite and all volatiles were removed from the filtrate in vacuum, whereby a colorless solid remained. Yield: $1.05 \mathrm{~g}(2.29 \mathrm{mmol}, 85 \%$ based on $\mathbf{1})$.

Anal. calcd for $\mathrm{C}_{21} \mathrm{H}_{20} \mathrm{AgO}_{3} \mathrm{P}: \mathrm{C}, 54.92 ; \mathrm{H}, 4.39 \%$; found: $\mathrm{C}$, 54.69; H, 4.47\%; mp $145^{\circ} \mathrm{C}$; IR ( $\left.\mathrm{KBr}, \mathrm{cm}^{-1}\right)$ v: $3056(\mathrm{w}), 2977$ (w), $1594(\mathrm{~m}), 1585$ (m), $1575\left(\mathrm{CO}_{2, \text { asym }}, \mathrm{s}\right), 1569$ (s), 1479 (m), 1436 (m), $1402\left(\mathrm{CO}_{2, \text { sym }}, \mathrm{m}\right), 1319(\mathrm{~m}), 1189(\mathrm{~m}), 1104$ (s), $1026(\mathrm{w}), 997(\mathrm{w}), 934(\mathrm{~m}), 907(\mathrm{w}), 754(\mathrm{~m}), 745(\mathrm{~m}), 706$ $(\mathrm{m}), 694(\mathrm{~s}) ;{ }^{1} \mathrm{H}$ NMR $\left(\mathrm{CDCl}_{3}\right) \delta 3.44\left(\mathrm{~s}, 3 \mathrm{H}, \mathrm{CH}_{3}\right), 4.05(\mathrm{~s}$, $\left.2 \mathrm{H}, \mathrm{CH}_{2}\right), 7.40-7.50\left(\mathrm{~m}, 15 \mathrm{H}, \mathrm{C}_{6} \mathrm{H}_{5}\right) ;{ }^{13} \mathrm{C}\left\{{ }^{1} \mathrm{H}\right\} \mathrm{NMR}\left(\mathrm{CDCl}_{3}\right)$ $\delta 59.0\left(\mathrm{CH}_{3}\right), 71.9\left(\mathrm{CH}_{2}\right), 129.4\left(\mathrm{~d},{ }^{3} J_{\mathrm{P}, \mathrm{C}}=11 \mathrm{~Hz},{ }^{\mathrm{m}} \mathrm{C} / \mathrm{C}_{6} \mathrm{H}_{5}\right)$, $130.0\left(\mathrm{~d},{ }^{1} J_{\mathrm{P}, \mathrm{C}}=40 \mathrm{~Hz},{ }^{\mathrm{i}} \mathrm{C} / \mathrm{C}_{6} \mathrm{H}_{5}\right), 131.5\left(\mathrm{~d},{ }^{4} J_{\mathrm{P}, \mathrm{C}}=2.0 \mathrm{~Hz},{ }^{\mathrm{p}} \mathrm{C} /\right.$ $\left.\mathrm{C}_{6} \mathrm{H}_{5}\right), 134.1\left(\mathrm{~d},{ }^{2} J_{\mathrm{PC}}=16 \mathrm{~Hz},{ }^{\circ} \mathrm{C} / \mathrm{C}_{6} \mathrm{H}_{5}\right) ;{ }^{11} \mathrm{P}\left\{{ }^{1} \mathrm{H}\right\} \mathrm{NMR}$ $\left(\mathrm{CDCl}_{3}\right) \delta 16.0\left(\mathrm{~s}, \mathrm{AgP}\left(\mathrm{C}_{6} \mathrm{H}_{5}\right)_{3}\right)$; HRMS (ESI-TOF) $\mathrm{m} / \mathrm{z}$ : calcd for $\mathrm{C}_{39} \mathrm{H}_{35} \mathrm{Ag}_{2} \mathrm{O}_{3} \mathrm{P}_{2}\left[\left(\mathrm{Ag}_{2}\left(\mathrm{O}_{2} \mathrm{CCH}_{2} \mathrm{OMe}\right)\left(\mathrm{PPh}_{3}\right)_{2}\right]^{+}, 827.0158\right.$; found, 827.0218; $\mathrm{C}_{36} \mathrm{H}_{30} \mathrm{AgP}_{2}\left[\left(\mathrm{Ag}\left(\mathrm{PPh}_{3}\right)_{2}\right]^{+}\right.$, 631.0874; found, 631.0864; $\mathrm{C}_{18} \mathrm{H}_{15} \mathrm{AgP}\left[\mathrm{AgPPh}_{3}\right]^{+}, 368.9962$; found, 368.9946; EIMS m/z (\%): $262(100)\left[\mathrm{PPh}_{3}\right]^{+}, 108(42)[\mathrm{PPh}]^{+}, 369(0.4)$ $\left[\mathrm{AgPPh}_{3}\right]^{+}$.

Crystal and structural refinement data for $2: \mathrm{C}_{21} \mathrm{H}_{20} \mathrm{AgO}_{3} \mathrm{P}$, $M=459.12 \mathrm{~g} \mathrm{~mol}^{-1}$, space group $C c, \lambda=9.71073 \AA$, $a=16.656(7) \AA, b=14.874(5) \AA, c=7.922(3) \AA$, $V=1960.0(13) \AA^{3}, Z=4, \delta_{\text {calcd. }}=1.556 \mathrm{~g} \mathrm{~cm}^{-3}$, $\mu=1.127 \mathrm{~mm}^{-1}, T=298 \mathrm{~K}, \theta$ range $2.449-24.989^{\circ}, 6332$ reflections collected, 3353 independent reflections, $\left(R_{\text {int }}=0.034\right), R_{1}=0.0369$ (all data), $w R_{2}=0.0624[I \geq 2 \sigma(I)]$. CCDC-No. 1552018.

\section{Theoretical studies}

The molecular monomeric structure of $\mathbf{2}$ and its fragmentation behavior under typical FEBID conditions was studied by Becke's three-parameter hybrid functional, applying the nonlocal correlation provided by Lee, Yang, and Parr (B3LYP) [12]. This study was performed with $3-21 \mathrm{G}$ for Ag and $6-31++\mathrm{G}^{* *}$ for the other atoms to satisfy both accuracy of the investigations and appropriate computing time and resources. The structure parameters of $\left[\mathrm{AgO}_{2} \mathrm{CCH}_{2} \mathrm{OMe}\left(\mathrm{PPh}_{3}\right)\right]$ and fragments thereof have been optimized with no symmetry constraint. The vibration frequencies were examined to check the optimization results accuracy. The zero-point energy was not included in the evaluation of the appearance energy because of their difference insignificancy. The potential of fragment appearance was calculated as the difference between the total energy of the molecule and the sum of the total energies of the fragments predicted. The calculations for the final states of the compounds are presented for the case of dissociation without taking into account the activation energy of the reverse reaction $\left(E_{\mathrm{r}}\right)$. The total number of the decomposition reactions investigated was $\approx 50$. The reactions of a dissociative ionization, dipolar dissociation, dissociative electron attachment etc. were studied to obtain the reaction pathways energetically most likely and relate to experimentally obtained species. It implies that the energetic of reactions leading from the intact neutral complex to different combinations of fragments were obtained and these results were used to deduce the most likely pathway. In this study we present only five decomposition ways, where the sum of the potential of appearance of the fragments, related to experimentally obtained species, is the lowest.

The electronegativity, chemical hardness and chemical softness were calculated as follows:

$$
\begin{gathered}
\chi=\frac{-I+A}{2} \text { (electonegativity) } \\
\eta=\frac{I-A}{2} \text { (chemical hardness) } \\
S=\frac{1}{2 \eta} \text { (chemical softness), }
\end{gathered}
$$

where $I$ and $A$ are the ionization potential and the electron affinity, respectively. The ionization potential and affinity were determined as difference of energies of ionized and neutral $\left[\mathrm{AgO}_{2} \mathrm{CCH}_{2} \mathrm{OMe}\left(\mathrm{PPh}_{3}\right)\right]$. Processes, where molecular ions are formed with energies in excess of the ionization potential, may possess not sufficient energy to be decomposed according to the lowest energy pathway, were also taken into account. The calculations were performed for molecular species and not for $1 \mathrm{D}$ coordination polymer 2 . Gaussian program packages were applied.

\section{Results and Discussion Chemical properties}

Coordination polymers $\mathbf{1}$ and $\mathbf{2}$ were prepared by a consecutive synthetic methodology as shown in Scheme 1. In this respect, $\mathrm{AgNO}_{3}$ was reacted with $\mathrm{HO}_{2} \mathrm{CCH}_{2} \mathrm{OMe}$ in a molar ratio of $1: 1$ in the presence of $\mathrm{NEt}_{3}$ to afford the respective silver(I) carboxylate $\left[\left\{\mathrm{AgO}_{2} \mathrm{CCH}_{2} \mathrm{OMe}\right\}_{n}\right](\mathbf{1})$, which gives $\left[\left\{\mathrm{AgO}_{2} \mathrm{CCH}_{2} \mathrm{OMe}\left(\mathrm{PPh}_{3}\right)\right\}_{n}\right](2)$, when treated with equimolar amounts of $\mathrm{PPh}_{3}$ (Scheme 1). 


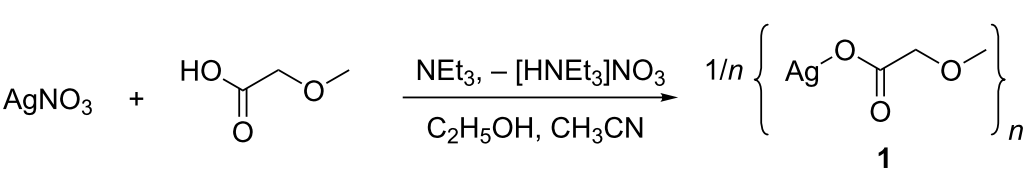

$$
\begin{aligned}
& \underset{\mathrm{CH}_{2} \mathrm{Cl}_{2}}{\mathrm{PPh}_{3}} 1 / n\left\{\mathrm{Ph}_{3} \mathrm{P}^{-} \mathrm{Ag}^{-} \prod_{\mathrm{O}} \mathrm{O}^{-}\right\}_{n}
\end{aligned}
$$

Scheme 1: Synthesis of $\left[\left\{\mathrm{AgO}_{2} \mathrm{CCH}_{2} \mathrm{OMe}\right\}_{n}\right]$ (1) and $\left[\left\{\mathrm{AgO}_{2} \mathrm{CCH}_{2} \mathrm{OMe}\left(\mathrm{PPh}_{3}\right)\right\}_{n}\right]$ (2).

Coordination polymers $\mathbf{1}$ and $\mathbf{2}$ are colorless solids, which are stable towards air and moisture and hence can be safely handled under aerobe conditions. Silver carboxylate 2 shows, in comparison to $\mathbf{1}$, an enhanced solubility in polar organic solvents such as dichloromethane and tetrahydrofuran, which is traced to the $\mathrm{PPh}_{3}$ ligand in 2 . In addition, this coordination compound possesses excellent light stability, since it can be stored under sun light for months. Further beneficial is that $\mathbf{1}$ and $\mathbf{2}$ do not undergo decomposition prior to evaporation with the loss or dissociation of any ligand below $150{ }^{\circ} \mathrm{C}$.

The identity of $\mathbf{1}$ was confirmed by elemental analysis and IR spectroscopy (Experimental), while 2 was additionally characterized by ${ }^{1} \mathrm{H},{ }^{13} \mathrm{C}\left\{{ }^{1} \mathrm{H}\right\}$ and ${ }^{31} \mathrm{P}\left\{{ }^{1} \mathrm{H}\right\}$ NMR (Experimental). An indication that in the silver(I) species $\mathbf{1}$ and $\mathbf{2} \mu$-bridging carboxylates are present can be deduced from the difference of the asymmetric and symmetric vibrations $\left(\Delta v_{\mathrm{CO} 2}=173 \mathrm{~cm}^{-1}\right)$ (Experimental). This value is close to the one obtained for the appropriate sodium salt $\left(\Delta v_{\mathrm{CO} 2}=192 \mathrm{~cm}^{-1} ; v_{\text {asym }}=1615 \mathrm{~cm}^{-1}\right.$, $v_{\text {sym }}=1423 \mathrm{~cm}^{-1}$ ), confirming that in the respective carboxylate complexes the organic ligand is $\mu$-bridging the silver atoms [13]. This bonding motif was confirmed by single crystal X-ray diffraction analysis of 2 (Figure 1).

In addition, EI and high-resolution ESI-TOF mass spectrometric investigations were carried out on 2. In the ESI experiments (Experimental), fragments such as $\left[\mathrm{Ag}\left(\mathrm{PPh}_{3}\right)\right]^{+}$, $\left[\mathrm{Ag}\left(\mathrm{PPh}_{3}\right)_{2}\right]^{+}$and $\left[\mathrm{Ag}_{2}\left(\mathrm{PPh}_{3}\right)_{2}\left(\mathrm{O}_{2} \mathrm{CCH}_{2} \mathrm{OMe}\right]^{+}\right.$could be detected, while EI experiments confirmed the formation of fragments such as $\left[\mathrm{AgPPh}_{3}\right]^{+}$of low intensity. As base peak $\mathrm{PPh}_{3}{ }^{+}$ was detected (Experimental; Supporting Information File 1, Figures S6 and S7). These results suggest the processing of $\mathbf{2}$ in nanoelectrospray liquid precursor injection as well as standard gas-phase FEBID [14].

Suitable single crystals of $\left[\left\{\mathrm{AgO}_{2} \mathrm{CCH}_{2} \mathrm{OMe}\left(\mathrm{PPh}_{3}\right)\right\}_{n}\right]$ were obtained by layering a concentrated solution of dichloromethane containing 2 with diethyl ether at ambient temperature. A representative cut-off of the $1 \mathrm{D}$ coordination polymer formed

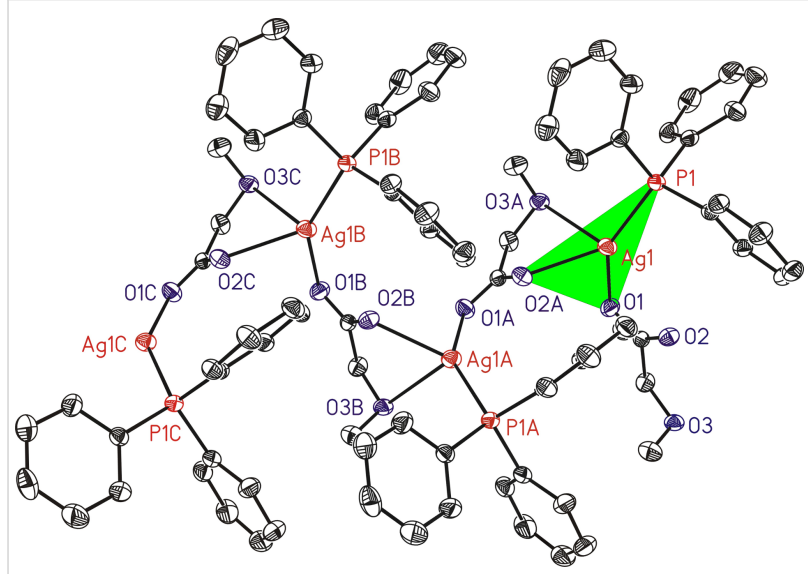

Figure 1: ORTEP ( $30 \%$ probability ellipsoids) of a selected part of the 1D coordination polymer formed by 2 in the solid state. All hydrogen atoms are omitted for clarity. The green triangle indicates the almost planar $\mathrm{AgPO}_{2}$ coordination units of the silver $(\mathrm{I})$ ions of 2 on a selected case. Symmetry used: "A" $=x,-y,-1 / 2+z$. "B" $=x, y,-z+1 / 2$. "C" $=x$, $-y,-3 / 2+z$. Selected bond lenghts $(\AA)$ and angles $\left({ }^{\circ}\right)$ : Ag1-O1 2.269(4), Ag1-P1 2.3474(18), Ag1-O2A 2.382(4), Ag1-O3A 2.667(3) bond angles: O1-Ag1-P1 144.76(12), O1-Ag1-O2A 84.37(15), P1-Ag1-O2A 130.59(11), O1-Ag1-O3A 89.03(11), P1-Ag1-O3A 107.91(8), O2-Ag1-O3A 65.91(10).

by 2 in the solid state is shown in Figure 1, selected bond distances and angles are given in its Figure caption.

In the solid state 2 forms 1D coordination polymers (Figure 1). Thereby, the carboxylate anions act as $\mu$-bridging ligands to link two adjacent silver(I) ions. Due to the coordination of a $\mathrm{PPh}_{3}$ group to $\mathrm{Ag}(\mathrm{I})$, virtually planar $\mathrm{AgPO}_{2}$ coordination units are observed. Planarity is revealed by the calculation of a mean plane. The average deviation from planarity amounts to $0.028 \AA$, while the highest deviation is observed for Ag1 with $0.048(1) \AA$. Furthermore, the sum of angles around Ag1 amounts to $359.8(2)^{\circ}$. The $\mathrm{P}-\mathrm{Ag}-\mathrm{O}$ angles $\left(144.76(12)^{\circ}\right.$ and $\left.130.59(11)^{\circ}\right)$ and the $\mathrm{O}-\mathrm{Ag}-\mathrm{O}$ angle $\left(84.37(16)^{\circ}\right)$ show that the geometry of the $\mathrm{AgPO}_{2}$ coordination units is closer to T-shaped than to trigonal planar. Related coordination polymers of phosphane stabilized silver(I) carboxylates are scarcely reported, i.e., [AgOC(O)C $\left.{ }_{2} \mathrm{~F}_{5}\left(\mathrm{PPh}_{3}\right)\right]$ [15] and [AgOAc(dppp)] [16] 
$(\mathrm{dppp}=$ diphenylphosphinopropane $)$. In both of them the silver(I) ions form $\mathrm{AgPO}_{2}$ coordination units as described for $\mathbf{2}$, although short $\mathrm{Ag}-\mathrm{Ag}$ contacts between these $\mathrm{AgPO}_{2}$ were observed [15,16]. In case of 2 a related stabilization of the $\mathrm{AgPO}_{2}$ units is not observed, although the formation of an additional dative $\mathrm{O}-\mathrm{Ag}$ bond is noticed (Figure 1 ) to give a $[3+1]$ coordination setup around the silver(I) ions. This bonding motif is most likely responsible for the little volatility of $\mathbf{2}$ (see below). Compound $\left[\left\{\mathrm{AgO}_{2} \mathrm{CCH}_{2} \mathrm{OMe}\left(\mathrm{PPh}_{3}\right)\right\}_{n}\right]$ (2) could be thus described as well as catena-poly $\{[$ triphenylphosphane- $\mathrm{KP}]$-silver$\mu$-methoxyacetate- $\left.\kappa \mathrm{O}^{3}, \kappa \mathrm{O}^{1}: \kappa \mathrm{O}^{2}\right\}$.

The thermal behavior of $\mathbf{1}$ and $\mathbf{2}$ in the solid state was studied by thermogravimetry (TG), thermogravimetry-coupled massspectrometry (TG-MS) and by differential scanning calorimetry (DSC).

The corresponding TG/DTG and DSC traces of $\mathbf{1}$ (argon, temperature range $100-500{ }^{\circ} \mathrm{C}$, heating rate $10{ }^{\circ} \mathrm{C} \min ^{-1}$ ) are depicted in Figure 2.

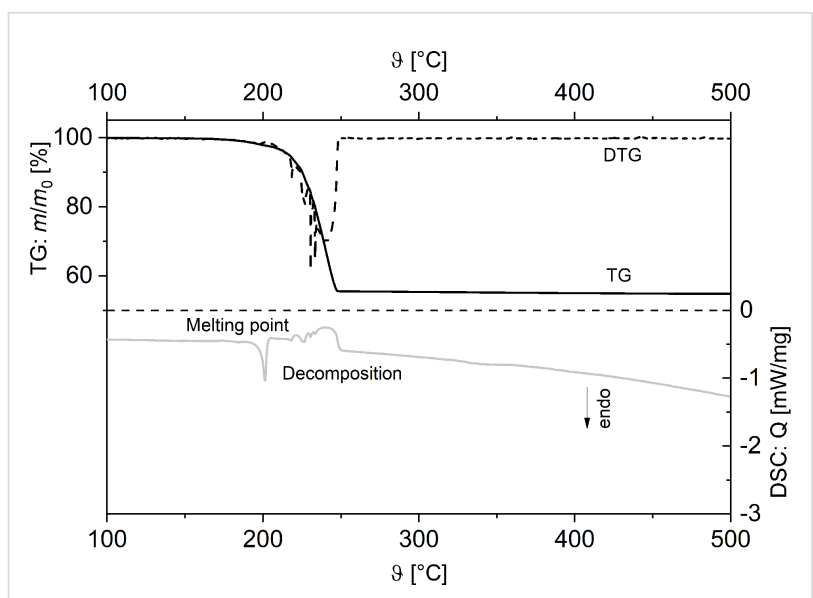

Figure 2: TG/DTG (top) and DSC (bottom) traces of 1 (Ar, gas flow $60 \mathrm{~mL} \mathrm{~min}^{-1}$, heating rate $10^{\circ} \mathrm{C} \mathrm{min}^{-1}$ ).

The decomposition of $\mathbf{1}$ occurs in consecutive steps, which were quantified with a mass loss of $\Delta m / m_{0}=45 \%$, matching to the formation of elemental silver (theoretical mass loss $\Delta m / m_{0}=45 \%$ ), which was confirmed by powder X-ray diffraction measurements (PXRD) (Supporting Information File 1, Figure S8).

The endothermic peak in the DSC study at $190{ }^{\circ} \mathrm{C}$ indicates the initial decomposition of $\mathbf{1}$, followed by an exothermic peak at $240{ }^{\circ} \mathrm{C}$.

In addition to TG/DTG and DSC measurements (Figure 2), TG-MS coupling experiments were carried out to gain a deeper insight into the thermal decomposition behavior of solid $\mathbf{1}$ (Figure 3).

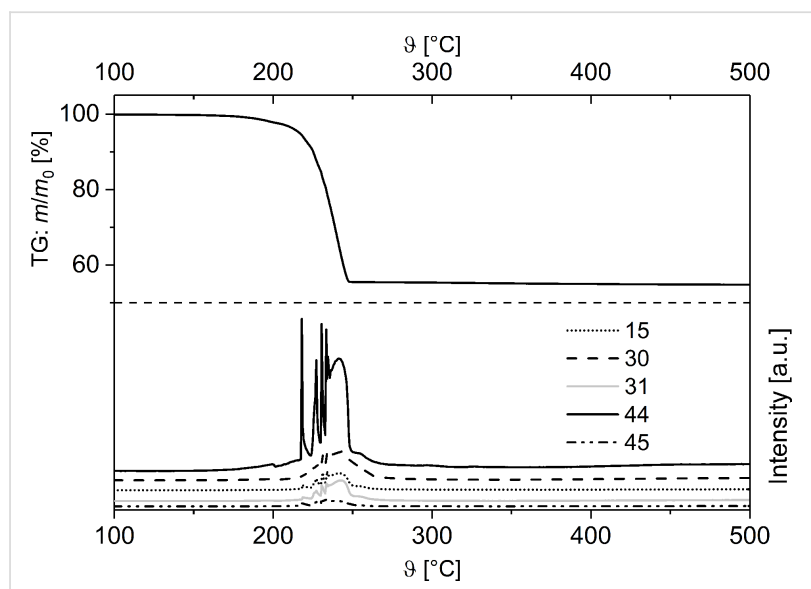

Figure 3: TG trace (Ar, gas flow $60 \mathrm{~mL} \mathrm{~min}^{-1}$, heating rate $10^{\circ} \mathrm{C} \mathrm{min}^{-1}$ ) and selected mass-spectrometric scans (bottom) of 1 : $\mathrm{m} / \mathrm{z}=45\left(\mathrm{C}_{2} \mathrm{H}_{5} \mathrm{O}^{+}\right), 44\left(\mathrm{CO}_{2}^{+}\right), 31\left(\mathrm{CH}_{3} \mathrm{O}^{+}\right), 30\left(\mathrm{CH}_{2} \mathrm{O}^{+}\right)$, and 15 $\left(\mathrm{CH}_{3}{ }^{+}\right)$.

As it can be seen from Figure 3, the decomposition of $\mathbf{1}$ occurs via elimination of carbon dioxide to give $\left[\mathrm{AgCH}_{2} \mathrm{OCH}_{3}\right]$. The evolution of $\mathrm{CO}_{2}$ is confirmed by the detection of the $\mathrm{CO}_{2}{ }^{+}$ fragment $(m / z=44)$ with high intensity. Subsequently, [ $\left.\mathrm{AgCH}_{2} \mathrm{OCH}_{3}\right]$ undergoes $\mathrm{Ag}-\mathrm{C}$ and $\mathrm{C}-\mathrm{O}$ bond cleavages, which is verified by the observation of characteristic fragments with $m / z=45\left(\mathrm{C}_{2} \mathrm{H}_{5} \mathrm{O}^{+}\right), 31\left(\mathrm{CH}_{3} \mathrm{O}^{+}\right), 30\left(\mathrm{CH}_{2} \mathrm{O}^{+}\right)$and 15 $\left(\mathrm{CH}_{3}{ }^{+}\right)$(Figure 3). The decomposition of 1 corresponds to that one recently observed for, i.e., $\left[\mathrm{AgO}_{2} \mathrm{CCH}_{2}\left(\mathrm{OCH}_{2} \mathrm{CH}_{2}\right)_{2} \mathrm{OCH}_{3}\right]$ and $\left[\mathrm{AgO}_{2} \mathrm{CCH}_{2}\left(\mathrm{OCH}_{2} \mathrm{CH}_{2}\right)_{2} \mathrm{OCH}_{3}\left(\mathrm{PPh}_{3}\right)\right]$, respectively [6].

TG/DTG and DSC studies of 2 show two endothermic processes at $145{ }^{\circ} \mathrm{C}$ and $260{ }^{\circ} \mathrm{C}$ (Figure 4), of which the first one corresponds to the melting of $\mathbf{2}$. However, weight loss of $\mathbf{2}$

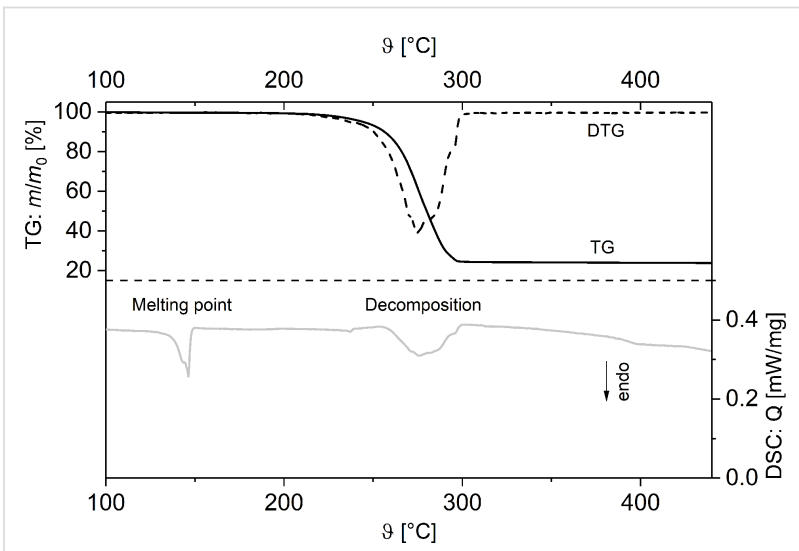

Figure 4: TG/DTG (top) and DSC (bottom) traces of 2 (Ar, gas flow $60 \mathrm{~mL} \mathrm{~min}^{-1}$, heating rate $5^{\circ} \mathrm{C} \mathrm{min}^{-1}$ ). 
during heat treatment can already be observed at $200{ }^{\circ} \mathrm{C}$, indicating partial evaporation passing over into decomposition, whereas the corresponding DSC signals, as well as vapor pressure measurements (Supporting Information File 1, Figure S9) suggest that decomposition starts at $260{ }^{\circ} \mathrm{C}$ and is completed at $300{ }^{\circ} \mathrm{C}$. Compared to $\mathbf{1}$, coordination polymer $\mathbf{2}$ shows a higher decomposition temperature.

The remaining residue at $500{ }^{\circ} \mathrm{C}$ amounts to $23.1 \%$, which is in agreement with the formation of elemental silver $(23.5 \%$ theoretical). The formation of silver was confirmed by PXRD measurements. In addition, TG-MS coupling experiments showed fragments at $m / z=45\left(\mathrm{C}_{2} \mathrm{H}_{5} \mathrm{O}^{+}\right), 44\left(\mathrm{CO}_{2}^{+}\right), 30\left(\mathrm{CH}_{2} \mathrm{O}^{+}\right), 31$ $\left(\mathrm{CH}_{3} \mathrm{O}^{+}\right)$and $15\left(\mathrm{CH}_{3}{ }^{+}\right)$, indicating $\mathrm{Ag}-\mathrm{O}, \mathrm{C}-\mathrm{C}$ and $\mathrm{C}-\mathrm{O}$ bond cleavages similar to 1 (Figure 5). However, no fragments for the dative-bonded $\mathrm{PPh}_{3}$ group could be detected under the measurement conditions applied (Experimental, Figure 5).

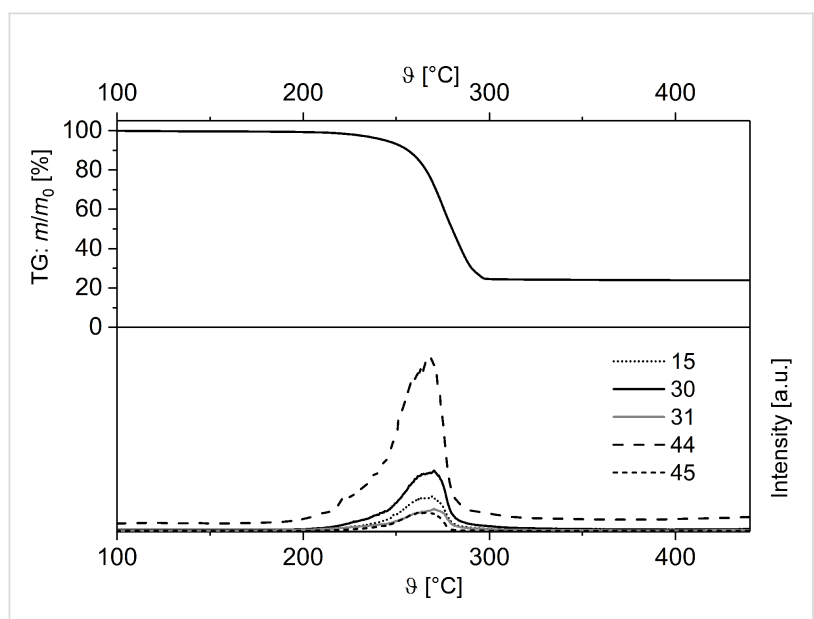

Figure 5: TG trace (top) (Ar, gas flow $60 \mathrm{~mL} \mathrm{~min}^{-1}$, heating rate

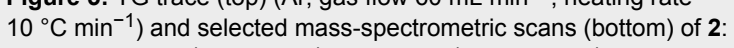
$\mathrm{m} / \mathrm{z}=45\left(\mathrm{C}_{2} \mathrm{H}_{5} \mathrm{O}^{+}\right), 44\left(\mathrm{CO}_{2}^{+}\right), 31\left(\mathrm{CH}_{3} \mathrm{O}^{+}\right), 30\left(\mathrm{CH}_{2} \mathrm{O}^{+}\right)$, and 15 $\left(\mathrm{CH}_{3}^{+}\right)$.

To show, if $\mathbf{2}$ is a suitable FEBID or chemical vapor deposition (CVD) precursor for the deposition of silver, vapor pressure measurements of 2 were undertaken (Figure 6). In order to determine the volatility of $\mathbf{2}$, a method was applied which originates from the mass-loss of the sample as a function of increasing temperature [17]. The mass-loss was defined by TG studies in an isothermal phase at different temperatures as described in [17]. The studies were carried out at atmospheric pressure under nitrogen (gas flow $60 \mathrm{~mL} \mathrm{~min}^{-1}$ ) (Figure 6). According to the TG studies, the measuring range was adjusted to $150-250{ }^{\circ} \mathrm{C}$, so it is ensured that $\mathbf{2}$ does not decompose during the measurement (for more details see Supporting Information File 1, Figure S9). These experiments were performed thrice to provide reliable data.

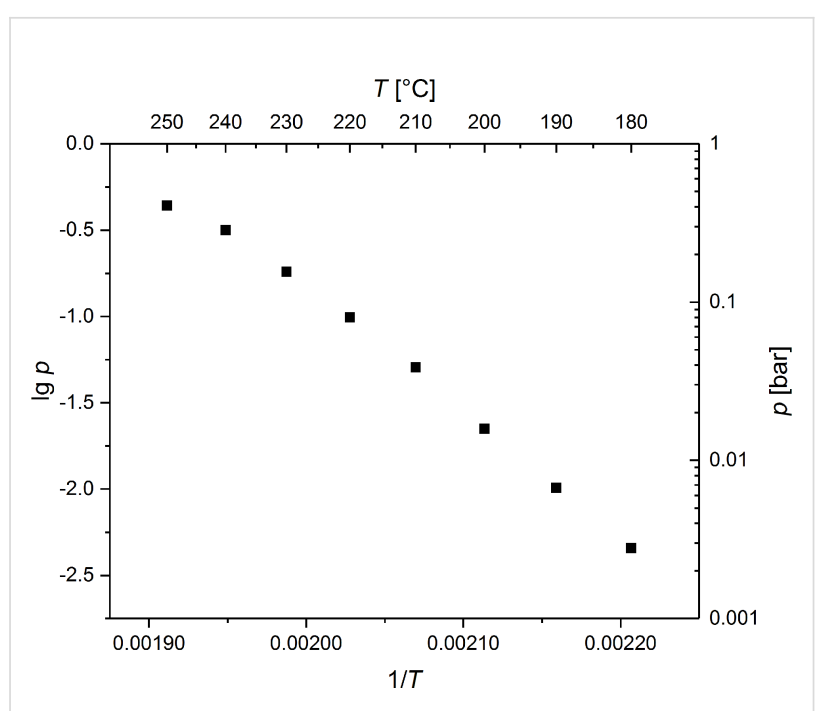

Figure 6: Vapor pressure of $2\left(\mathrm{~N}_{2}\right.$, gas flow $\left.60 \mathrm{~mL} \mathrm{~min}{ }^{-1}\right)$.

The linear regression of the data is given by the characteristic Antoine parameters according to the Antoine Equation 1,

$$
\log p=A-B / T
$$

whereby $\mathrm{A}=12.562$ and $\mathrm{B}=6574.7$ with a coefficient of determination of $\mathrm{R}^{2}=0.9951$.

Based on these values the vapor pressure was determined to $P=5.318$ mbar at $170{ }^{\circ} \mathrm{C}$, with an evaporation enthalpy of $\Delta H_{\text {vap }}=126.1 \mathrm{~kJ} \mathrm{~mol}^{-1}$.

These data approve that $\mathbf{2}$ is confined to be used as CVD precursor. In addition to the mass-spectrometric and vapor pressure measurements (see earlier), it was proven that coordination compound $\mathbf{2}$ can experimentally brought into the vapor phase. Therefore, 2 was heated to $120^{\circ} \mathrm{C}$ at a pressure of $5 \times 10^{-2}$ mbar in a Schlenk tube fitted with a sublimation finger. The corresponding sublimate was characterized by NMR and IR spectroscopy. Heating to a temperature above $260{ }^{\circ} \mathrm{C}$ gave a silver deposit.

To proof if $\mathbf{2}$ is an appropriate FEBID precursor for silver deposition under electron impact, DFT/B3LYP calculations were additionally performed on monomeric $\left[\mathrm{AgO}_{2} \mathrm{CCH}_{2} \mathrm{OMe}\left(\mathrm{PPh}_{3}\right)\right]$ (Experimental).

Pure metals are formed, when a chemical reaction is initiated by electrons [1], i.e., the respective precursor should be chemically stable. The calculated values of hardness and softness of monomeric 2 are equal to $3.35 \mathrm{eV}$ and $0.15 \mathrm{eV}$, respectively. For comparison, silver(I) complex $\left[\mathrm{Ag}(\mathrm{hfac})\left(\mathrm{PMe}_{3}\right)\right]$ 
(hfac $=(1,1,1,5,5,5$-hexafluoropentanedionate), which was successfully used as CVD precursor for the deposition of silver, possesses values of $3.65 \mathrm{eV}$ and $0.13 \mathrm{eV}$ [18]. Values of the hardness $>3 \mathrm{eV}$ and softness $<0.1 \mathrm{eV}$ indicate high chemical stability and hence 2 can be considered as such, indicating reliability of the approach applied. This nicely corresponds with the experimentally observed properties of $\mathbf{2}$ (see above).

The electronic structure of monomeric 2 is similar to that of metal carbonyls [1]. For example, referring to results of our investigations, the Mulliken atomic charge of the silver atom is 0.27 , which is smaller than 1.30 or 0.69 of iron or nickel atoms, consisting of the most prominent carbonyls used as precursors for FEBID [19]. In any case, the small charge on silver should be in agreement with the principle of electro-neutrality: "Stable complexes are those with structures such that each atom has only a small electric charge" [19]. On the other hand, deposition processes using complexes featuring low charged metals produce higher metal contents than highly charged metal ions [1].

One requirement for a FEBID metal precursor is that the appearance energy of the fragments formed during the dissociation process does not exceed the energy of FEBID. The relevant energy range for FEBID is $1 \mathrm{meV}$ (slowed-down secondary electrons) and up to the $\mathrm{keV}$ regime (typical primary electron regime, forward and backscattered electrons) [19]. Hence, 50 possible fragmentation routes of mononuclear 2 under low electron impact were studied. The appearance energy $E_{\text {ap }}$ was calculated for all ions shown below (2)

$$
E_{\text {ap }}=\left|E_{\mathrm{t}}\right|-\left|\Sigma\left(E_{i}\right)\right|
$$

$\left(E_{\mathrm{t}}=\right.$ total energy of neutral 2, $E_{i}=$ total energy of all fragments produced during dissociation).

However, this calculation does not take the activation energy of the molecular ion fragmentation into account. Subsequently, only the most favorable fragmentation routes according to the lowest energy pathways are considered, which are pathways A-C.

\section{Fragmentation according to pathway $\mathrm{A}$}

The energies of the fragments formed during the decomposition of $\mathbf{2}$ concerning pathway A are summarized in Table 1 and Table 2. Here and further, the total charge of the compound consisting of isolated fragments is given. In some cases the additional analysis of the Mulliken charge of the compound was performed to exhibit which fragment carries the positive, negative or neutral charge.
Table 1: Appearance energy (Equation 2) of differently charged Ag and $\mathrm{Ph}_{3} \mathrm{P} / \mathrm{O}_{2} \mathrm{CCH}_{2} \mathrm{OMe}$ fragments from dissociation of mononuclear 2.

\begin{tabular}{rrr} 
Ag charge & $\mathrm{Ph}_{3} \mathrm{P} / \mathrm{O}_{2} \mathrm{CCH}_{2} \mathrm{OMe} \mathrm{charge}$ & $E_{\mathrm{ap}}^{\mathrm{a}}[\mathrm{eV}]$ \\
\hline-1 & -1 & 0.79 \\
-1 & 0 & 3.82 \\
-1 & 1 & 8.37 \\
0 & -1 & 1.48 \\
0 & 0 & 4.52 \\
0 & 1 & 9.07 \\
1 & -1 & 8.29 \\
1 & 0 & 11.32 \\
1 & 1 & 15.87 \\
\hline
\end{tabular}

${ }^{a} \mathrm{Ph}_{3} \mathrm{P} / \mathrm{O}_{2} \mathrm{CCH}_{2} \mathrm{OMe}$ charge indicates the total charge of the compound consisting of $\mathrm{Ph}_{3} \mathrm{P}$ and $\mathrm{O}_{2} \mathrm{CCH}_{2} \mathrm{OMe}$ fragments.

Table 2: Appearance energy (Equation 2) of differently charged $\mathrm{O}_{2} \mathrm{C}$ and $\mathrm{CH}_{2} \mathrm{OMe}$ fragments from dissociation of $\mathrm{O}_{2} \mathrm{CCH}_{2} \mathrm{OMe}^{-}$.

\begin{tabular}{rrr}
$\mathrm{CO}_{2}$ charge & $\mathrm{CH}_{2} \mathrm{OMe}$ charge & $E_{\mathrm{ap}}[\mathrm{eV}]$ \\
\hline 0 & -1 & 1.37 \\
0 & 0 & 1.21 \\
0 & 1 & 8.25 \\
1 & -1 & 15.23 \\
1 & 0 & 15.07 \\
1 & 1 & 22.11 \\
& &
\end{tabular}

From Table 1 it can be seen that the formation of negatively charged $\mathrm{Ph}_{3} \mathrm{P} / \mathrm{O}_{2} \mathrm{CCH}_{2} \mathrm{OMe}^{-}$and negatively charged $\mathrm{Ag}^{-}$ requires the smallest energy of all investigated cases. The fragmentation concerning $\operatorname{Ag}(0)$ formation, according to the value of the appearance energy, requires $1.48 \mathrm{eV}$, which is $\approx 0.7 \mathrm{eV}$ higher compared to the most favorable decomposition process (pathway A). Mulliken charge analysis indicates that the negative charge mostly residues on the $\mathrm{O}_{2} \mathrm{CCH}_{2} \mathrm{OMe}$ fragment and hence the following process is most likely

$$
\begin{aligned}
& {\left[\mathrm{AgO}_{2} \mathrm{CCH}_{2} \mathrm{OMe}\left(\mathrm{PPh}_{3}\right)\right]+(n) \mathrm{e}} \\
& \Rightarrow \mathrm{Ag}^{-}+\mathrm{Ph}_{3} \mathrm{P}+\mathrm{O}_{2} \mathrm{CCH}_{2} \mathrm{OMe}^{-}+(n-2) \mathrm{e}
\end{aligned}
$$

Hence, for the process $0.79 \mathrm{eV}$ are necessary to produce a negatively charged $\mathrm{Ag}^{-}$ion. However, the decarboxylation of negatively charged $\mathrm{O}_{2} \mathrm{CCH}_{2} \mathrm{OMe}^{-}$could occur as alternative reaction route (decomposition pathways $\mathrm{B}$ and $\mathrm{C}$ ). In this respect, the energy of the variously charged $\mathrm{CO}_{2}$ and $\mathrm{CH}_{2} \mathrm{OMe}$ fragments were determined, showing that at least $1.21 \mathrm{eV}$ are necessary for the decarboxylation of the $\mathrm{O}_{2} \mathrm{CCH}_{2} \mathrm{OMe}^{-}$fragment (Table 2). In summary, referring to the calculated data (Table 2), the most favorable fragmentation process, according 
to pathway $\mathrm{A}$, requires at least $0.79 \mathrm{eV}$ for the formation of $\mathrm{Ag}^{-}$ and at least $1.21 \mathrm{eV}$ for the decarboxylation of the negatively charged $\mathrm{O}_{2} \mathrm{CCH}_{2} \mathrm{OMe}^{-}$fragment.

\section{Fragmentation according to pathway $\mathrm{B}$}

The formation of $\left[\mathrm{AgO}_{2} \mathrm{CCH}_{2} \mathrm{OMe}\right]$ from neutral mononuclear 2 requires less energy than the removal of $\mathrm{Ag}$ from mononuclear 2 (Table 3). It was found that the development of the negatively charged $\left[\mathrm{AgO}_{2} \mathrm{CCH}_{2} \mathrm{OMe}\right]^{-}$fragment is most favorable, which is based on the appearance energy, which is with $0.44-0.55 \mathrm{eV}$ (Table 3 ) very low. Hence, the electron-induced decomposition processes can be formulated as

$$
\begin{aligned}
& {\left[\mathrm{AgO}_{2} \mathrm{CCH}_{2} \mathrm{OMe}\left(\mathrm{PPh}_{3}\right)\right]+(n) \mathrm{e}} \\
& \Rightarrow \mathrm{Ph}_{3} \mathrm{P}^{-}+\left[\mathrm{AgO}_{2} \mathrm{CCH}_{2} \mathrm{OMe}\right]^{-}+(n-2) \mathrm{e} \\
& {\left[\mathrm{AgO}_{2} \mathrm{CCH}_{2} \mathrm{OMe}\left(\mathrm{PPh}_{3}\right)\right]+(n) \mathrm{e}} \\
& \Rightarrow \mathrm{Ph}_{3} \mathrm{P}^{0}+\left[\mathrm{AgO}_{2} \mathrm{CCH}_{2} \mathrm{OMe}\right]^{-}+(n-1) \mathrm{e}
\end{aligned}
$$

However, release of $\mathrm{Ag}$ from $\left[\mathrm{AgO}_{2} \mathrm{CCH}_{2} \mathrm{OMe}\right]^{-}$requires at least $0.75 \mathrm{eV}$ (Table 4).

Table 3: Appearance energy (Equation 2) of differently charged $\mathrm{Ph}_{3} \mathrm{P}$ and $\left[\mathrm{AgO}_{2} \mathrm{CCH}_{2} \mathrm{OMe}\right]$ fragments from dissociation of monomeric 2 .

\begin{tabular}{rrr}
$\mathrm{Ph}_{3} \mathrm{P}$ charge & $\mathrm{Ag}\left(\mathrm{O}_{2} \mathrm{CCH}_{2} \mathrm{OMe}\right)$ charge & $E_{\mathrm{ap}}[\mathrm{eV}]$ \\
\hline-1 & -1 & 0.55 \\
-1 & 0 & 1.77 \\
-1 & 1 & 9.97 \\
0 & -1 & 0.44 \\
0 & 0 & 1.66 \\
0 & 1 & 9.87 \\
1 & -1 & 7.42 \\
1 & 0 & 8.64 \\
1 & 1 & 16.84
\end{tabular}

Table 4: Appearance energy (Equation 2) of differently charged Ag and $\mathrm{O}_{2} \mathrm{CCH}_{2} \mathrm{OMe}$ fragments from dissociation of $\left[\mathrm{AgO}_{2} \mathrm{CCH}_{2} \mathrm{OMe}\right]^{-}$.

\begin{tabular}{rrr} 
Ag charge & $\mathrm{O}_{2} \mathrm{CCH}_{2} \mathrm{OMe}$ charge & $E_{\mathrm{ap}}[\mathrm{eV}]$ \\
\hline-1 & -1 & 0.75 \\
-1 & 0 & 3.26 \\
-1 & 1 & 10.11 \\
0 & -1 & 1.45 \\
0 & 0 & 3.96 \\
0 & 1 & 10.81 \\
1 & -1 & 8.25 \\
1 & 0 & 10.76 \\
1 & 1 & 17.61 \\
\hline
\end{tabular}

Based on the data obtained (Table 4), the most favorable decomposition process is

$$
\begin{aligned}
& {\left[\mathrm{AgO}_{2} \mathrm{CCH}_{2} \mathrm{OMe}\right]^{-}+(n) \mathrm{e}} \\
& \Rightarrow \mathrm{Ag}^{-}+\mathrm{O}_{2} \mathrm{CCH}_{2} \mathrm{OMe}^{-}+(n-1) \mathrm{e},
\end{aligned}
$$

which agrees with pathway $\mathrm{A}$, i.e., the building of $\mathrm{Ag}^{-}$ and $\mathrm{O}_{2} \mathrm{CCH}_{2} \mathrm{OMe}^{-}$, respectively. From negatively charged $\mathrm{O}_{2} \mathrm{CCH}_{2} \mathrm{OMe}^{-} \mathrm{CO}_{2}$ is released. For this decomposition path the $\mathrm{Ag}$ appearance energy, according to the lowest energy pathways, is equal to 1.19 or $1.30 \mathrm{eV}$. It is larger than the $E_{\text {ap }}$ of anionic $\mathrm{Ag}^{-}$directly from $\left[\mathrm{AgO}_{2} \mathrm{CCH}_{2} \mathrm{OMe}\left(\mathrm{PPh}_{3}\right)\right]$.

In conclusion, the decomposition of mononuclear 2 under FEBID conditions occurs preferably via pathway A, when com-

\begin{tabular}{|c|c|c|}
\hline $\mathrm{CO}_{2}$ charge & $\mathrm{Ag}\left(\mathrm{CH}_{2} \mathrm{OMe}\right)\left(\mathrm{Ph}_{3} \mathrm{P}\right)$ charge & $E_{\text {ap }}[\mathrm{eV}]$ \\
\hline 0 & -1 & 1.18 \\
\hline 0 & 0 & 0.80 \\
\hline 0 & 1 & 6.90 \\
\hline 1 & -1 & 15.50 \\
\hline 1 & 0 & 14.67 \\
\hline 1 & 1 & 20.77 \\
\hline
\end{tabular}
pared to B.

\section{Fragmentation accordingly to pathway $\mathrm{C}$}

The investigation of the fragmentation according to pathway $\mathrm{C}$ indicates that decarboxylation of mononuclear 2 requires at least $0.8 \mathrm{eV}$ (Table 5).

Due to the lowest $E_{\text {ap }}$ (Equation 2), the formation of the neutral $\mathrm{CO}_{2}$ and $\left[\mathrm{AgCH} \mathrm{H}_{2} \mathrm{OMe}\left(\mathrm{PPh}_{3}\right)\right]$ fragments are the most favorable ones. It is interesting to note that the elimination of $\mathrm{PPh}_{3}$ from $\left[\mathrm{AgCH} \mathrm{H}_{2} \mathrm{OMe}\left(\mathrm{PPh}_{3}\right)\right]$ is a spontaneous reaction as indicated by the negative values of the free Gibbs energy (Table 6), allowing to predict following most favorable processes

$$
\begin{aligned}
& {\left[\mathrm{AgCH}_{2} \mathrm{OMe}\left(\mathrm{PPh}_{3}\right)\right]+(n) \mathrm{e}} \\
& \Rightarrow \mathrm{PPh}_{3}{ }^{-}+\left[\mathrm{AgCH}_{2} \mathrm{OMe}\right]^{-}+(n-2) \mathrm{e} \\
& {\left[\mathrm{AgCH}_{2} \mathrm{OMe}\left(\mathrm{PPh}_{3}\right)\right] \Rightarrow \mathrm{PPh}_{3}{ }^{0}+\left[\mathrm{AgCH}_{2} \mathrm{OMe}\right]}
\end{aligned}
$$

The appearance energy of negatively charged and neutral [AgCH $\mathrm{AH}_{2} \mathrm{OMe}$, amounts to 1.45 and $1.34 \mathrm{eV}$, respectively. 
Table 6: Appearance energy (Equation 2) and free Gibbs energy of differently charged $\mathrm{Ph}_{3} \mathrm{P}$ and $\mathrm{AgCH}_{2} \mathrm{OMe}$ fragments from dissociation of $\left[\mathrm{AgCH}_{2} \mathrm{OMe}\left(\mathrm{PPh}_{3}\right)\right]$.

\begin{tabular}{rrrr}
$\begin{array}{r}\mathrm{Ph}_{3} \mathrm{P} \\
\text { charge }\end{array}$ & $\begin{array}{r}\mathrm{AgCH}_{2} \mathrm{OMe} \\
\text { charge }\end{array}$ & $E_{\mathrm{ap}}[\mathrm{eV}]$ & $\begin{array}{r}\text { Free Gibbs energy } \\
\text { [kcal/mol] }\end{array}$ \\
\hline-1 & -1 & 1.45 & -2.35 \\
-1 & 0 & 1.82 & 8.09 \\
-1 & 1 & 8.66 & 164.59 \\
0 & 0 & 1.34 & -0.89 \\
0 & 1 & 1.72 & 9.55 \\
0 & 0 & 8.55 & 166.05 \\
1 & 1 & 8.32 & 160.57 \\
1 & 0 & 8.69 & 171.01 \\
1 & -1 & 15.53 & 327.52 \\
& & &
\end{tabular}

$E_{\text {ap }}$ of $\mathrm{Ag}^{-}$is smaller than those of neutral or positively charged silver (Table 7 and Table 8), forming from both the negatively charged or neutral $\left[\mathrm{Ag}\left(\mathrm{CH}_{2} \mathrm{OMe}\right)\right]$ fragments.

Table 7: Appearance energy (Equation 2) of differently charged $\mathrm{Ag}$ and $\mathrm{CH}_{2} \mathrm{OMe}$ fragments from dissociation of $\left[\mathrm{AgCH}_{2} \mathrm{OMe}\right]^{-}$.

\begin{tabular}{rrr} 
Ag charge & $\mathrm{CH}_{2}$ OMe charge & $E_{\mathrm{ap}}[\mathrm{eV}]$ \\
\hline-1 & -1 & 1.80 \\
-1 & 0 & 1.64 \\
-1 & 1 & 8.68 \\
0 & -1 & 2.50 \\
0 & 0 & 2.34 \\
0 & 1 & 9.38 \\
1 & -1 & 9.30 \\
1 & 0 & 9.14 \\
1 & 1 & 16.18 \\
\end{tabular}

Table 8: Appearance energy (Equation 2) of differently charged Ag and $\mathrm{CH}_{2} \mathrm{OMe}$ fragments from dissociation of $\left[\mathrm{AgCH}_{2} \mathrm{OMe}\right]$.

\begin{tabular}{rrr} 
Ag charge & $\mathrm{CH}_{2}$ OMe charge & $E_{\mathrm{ap}}[\mathrm{eV}]$ \\
\hline-1 & -1 & 1.43 \\
-1 & 0 & 1.27 \\
-1 & 1 & 8.31 \\
0 & -1 & 2.13 \\
0 & 0 & 1.97 \\
0 & 1 & 9.01 \\
1 & -1 & 8.93 \\
1 & 0 & 8.77 \\
1 & 1 & 15.81
\end{tabular}

The comparison of $E_{\text {ap }}$ of $\mathrm{Ag}^{-}$allows to state that the most favorable fragmentation of $\left[\mathrm{AgCH} \mathrm{CH}_{2} \mathrm{OMe}\right]$, according to the lowest energy pathway, is

$$
\left[\mathrm{AgCH}_{2} \mathrm{OMe}\right]+(\mathrm{n}) \mathrm{e} \Rightarrow \mathrm{Ag}^{-}+\mathrm{CH}_{2} \mathrm{OMe}^{0}+(\mathrm{n}-1) \mathrm{e} .
$$

The formation of the negatively charged ion $\mathrm{Ag}^{-}$is the result of the most favorable dissociation reaction, according to the lowest energy pathways $\mathrm{A}$ and $\mathrm{B}$. The total appearance energy of Ag is equal to 3.41-3.52 eV, which is much larger than those of pathways A and B. Hence, both the A and B pathways can be realized, when the energy range for FEBID should be up to $0.8 \mathrm{eV}$, while pathway $\mathrm{C}$ is more favored, when the energy of the secondary electrons will be $1.3 \mathrm{eV}$.

\section{Conclusion}

The consecutive synthesis of $\left[\left\{\mathrm{AgO}_{2} \mathrm{CCH}_{2} \mathrm{OMe}\left(\mathrm{PPh}_{3}\right)\right\}_{n}\right]$ (2) by the reaction of $\mathrm{AgNO}_{3}$ with the carboxylic acid $\mathrm{HO}_{2} \mathrm{CCH}_{2} \mathrm{OMe}$ and treatment of thereby formed $\left[\left\{\mathrm{AgO}_{2} \mathrm{CCH}_{2} \mathrm{OMe}\right\}_{n}\right]$ (1) with $\mathrm{PPh}_{3}$ is reported. The chemical, thermal and structural properties of $\mathbf{2}$ are reported. Complex $\mathbf{2}$ forms a $1 \mathrm{D}$ coordination polymer in the solid state in which the silver(I) ions are involved in distorted T-shaped planar $\mathrm{AgPO}_{2}$ coordination units, which are additionally stabilized by an $\mathrm{O}-\mathrm{Ag}$ dative bond. The thermal initiated decomposition of $\mathbf{1}$ and $\mathbf{2}$ in the solid state was determined by thermogravimetry and differential scanning calorimetry. It was found that $\mathbf{2}$ possesses a somewhat higher onset temperature as $\mathbf{1}$, which is related to the different structure of both complexes. The mechanism of dissociation for both species was studied using thermogravimetry-coupled mass spectrometry confirming that $\mathbf{1}$ decarboxylates at first followed by $\mathrm{Ag}-\mathrm{C}, \mathrm{C}-\mathrm{C}$ and $\mathrm{C}-\mathrm{O}$ bond cleavages. The remaining residue was characterized as elemental silver by PXRD. Also, coordination polymer 2 most likely decomposes by elimination of $\mathrm{CO}_{2}$ and $\mathrm{PPh}_{3}$ and the thus formed $\left[\mathrm{AgCH}_{2} \mathrm{OMe}\right.$ ] fragment dissociates as discussed for $\mathbf{1}$. Vapor pressure measurements showed that $\mathbf{2}$ is little volatile, despite its polymeric structure, while $\mathbf{1}$ cannot be evaporated. Also EI and ESI mass spectrometric studies and sublimation experiments were carried out with 2 , indicating its usability in nanoelectrospray liquid precursor injection [14] as well as in standard gas-phase FEBID processes for silver deposition.

Based on the chemical and physical properties of 2 and on the appearance energy of silver, DFT (B3LYP) calculations were carried out to determine the decomposition pathways for mononuclear $\left[\mathrm{AgO}_{2} \mathrm{CCH}_{2} \mathrm{OMe}\left(\mathrm{PPh}_{3}\right)\right]$. Three lowest energy dissociation routes exist: (i) Pathway A: Electron-induced decomposition of mononuclear 2 occurs via the formation of $\mathrm{Ag}^{-}$, $\mathrm{O}_{2} \mathrm{CCH}_{2} \mathrm{OMe}^{-}$and $\mathrm{Ph}_{3} \mathrm{P}$. From $\mathrm{O}_{2} \mathrm{CCH}_{2} \mathrm{OMe}^{-}, \mathrm{CO}_{2}$ is released. Pathway B: Elimination of $\mathrm{PPh}_{3}$ takes place at first affording $\left[\mathrm{AgO}_{2} \mathrm{CCH}_{2} \mathrm{OMe}\right]^{-}$from which the fragments $\mathrm{Ag}^{-}$ and $\mathrm{O}_{2} \mathrm{CCH}_{2} \mathrm{OMe}^{-}$occur. Pathway $\mathrm{C}$ : Decarboxylation of mononuclear 2 takes place producing $\left[\mathrm{AgCH} \mathrm{OHe}_{2}\left(\mathrm{PPh}_{3}\right)\right]$, which afterwards releases $\mathrm{PPh}_{3}$ forming $\left[\mathrm{AgCH}_{2} \mathrm{OMe}\right]$, which 
further decomposes to Ag. Both the A and B pathways are most favored, when the energy range for FEBID is up to $0.8 \mathrm{eV}$, while pathway $\mathrm{C}$ is preferred, when the energy of the secondary electrons will be up $1.3 \mathrm{eV}$.

\section{Supporting Information}

\section{Supporting Information File 1}

Additional figures and tables.

[http://www.beilstein-journals.org/bjnano/content/

supplementary/2190-4286-8-262-S1.pdf]

\section{Acknowledgements}

This work was conducted within the framework of the COST Action CM1301 (CELINA) and within the Federal Cluster of Excellence EXC 1075 MERGE Technologies for Multifunctional Lightweight Structures and supported by the German Research Foundation (DFG). Special thanks are given to the Digital Computing Centre of Vilnius University for the resources and technical support provided. We also acknowledge Dipl.-Chem. Lutz Mertens and Prof. Dr. Michael Mehring for the PXRD analyses. Ms. Oehme, Universität Leipzig is gratefully acknowledged for carrying out the EI mass-spectrometric measurements. These coordination complexes are described in the dissertation of Dr. Alexander Jakob (http://nbnresolving.de/urn:nbn:de:bsz:ch1-200900713).

\section{References}

1. Utke, I.; Jenke, M. G.; Roeling, C.; Thiesen, P. H.; lakovlev, V.; Sirbu, A.; Mereuta, A.; Caliman, A.; Kapon, E. Nanoscale 2011, 3 , 2718-2722. doi:10.1039/c1nr10047e

2. Toth, M.; Lobo, C.; Friedli, V.; Szkudlarek, A.; Utke, I. Beilstein J. Nanotechnol. 2015, 6, 1518-1540. doi:10.3762/bjnano.6.157

3. Höflich, K.; Becker, M.; Leuchs, G.; Christiansen, S. Nanotechnology 2012, 23, 185303. doi:10.1088/0957-4484/23/18/185303

4. Huth, M.; Porrati, F.; Schwalb, C.; Winhold, M.; Sachser, R.; Dukic, M.; Adams, J.; Fantner, G. Beilstein J. Nanotechnol. 2012, 3, 597-619. doi:10.3762/bjnano.3.70

5. Botman, A.; Mulders, J. J. L.; Hagen, C. W. Nanotechnology 2009, 20, 372001. doi:10.1088/0957-4484/20/37/372001

6. Adner, D.; Noll, J.; Schulze, S.; Hietschold, M.; Lang, H. Inorg. Chim. Acta 2016, 446, 19-23. doi:10.1016/j.ica.2016.02.059

7. Niskanen, A.; Hatanpää, T.; Arstila, K.; Leskelä, M.; Ritala, M. Chem. Vap. Deposition 2007, 13, 408-413. doi:10.1002/cvde.200606519

8. Lang, H.; Dietrich, H. S. 4.10 - Metals - Gas-Phase Deposition and Applications. In Comprehensive Inorganic Chemistry II, 2nd ed.; Reedijk, J.; Poeppelmeier, K., Eds.; Elsevier: Amsterdam, Netherlands, 2013; Vol. 4, pp 211-269. doi:10.1016/b978-0-08-097774-4.00412-5
9. Lang, H.; Buschbeck, R. Deposition of metals and metal oxides by means of metal enolates. In The Chemistry of Metal Enolates; Zabicky, J., Ed.; Wiley: Chichester, United Kingdom, 2009; pp 929-1017. doi:10.1002/9780470682531.pat0433

10. Sheldrick, G. M. Acta Crystallogr., Sect. A 2008, 64, 112-122. doi:10.1107/S0108767307043930

11. Jakob, A. Synthese und Reaktionsverhalten von Übergangsmetallkomplexen sowie deren Verwendung in der Homogenen Katalyse und Metallabscheidung. Ph.D. Thesis, TU Chemnitz, 2009. http://nbn-resolving.de/urn:nbn:de:bsz:ch1-200900713

12. Dobbs, K. D.; Hehre, W. J. J. Comput. Chem. 1987, 8, 880-893. doi:10.1002/jcc.540080615

13. Nakamoto, K. Part B: Applications in Corrdination, Organometallic, and Bioinorganic Chemistry, 6th ed.; John Wiley \& Sons, Inc.: Hoboken, NJ, U.S.A., 2009.

14. Fisher, J. S.; Kottke, P. A.; Kim, S.; Fedorov, A. G. Nano Lett. 2015, 15, 8385-8391. doi:10.1021/acs.nanolett.5b04225

15. Römbke, P.; Schier, A.; Schmidbaur, A.; Cronje, S.; Raubenheimer, R. Inorg. Chim. Acta 2004, 357, 235-242. doi:10.1016/S0020-1693(03)00468-7

16. Cingolani, A.; Effendy; Pettinari, C.; Skelton, B. W.; White, A. H. Inorg. Chim. Acta 2006, 359, 2170-2177. doi:10.1016/j.ica.2005.12.015

17. Tuchscherer, A.; Georgi, C.; Roth, N.; Schaarschmidt, D.; Rüffer, T.; Waechtler, T.; Schulz, S. E.; Oswald, S.; Gessner, T.; Lang, H. Eur. J. Inorg. Chem. 2012, 4867-4876. doi:10.1002/ejic.201200601 18. Dryden, N. H.; Vittal, J. J.; Puddephatt, R. J. Chem. Mater. 1993, 5 , 765-766. doi:10.1021/cm00030a008

19. Farrugia, L. J.; Evans, C. J. Phys. Chem. A 2005, 109, 8834-8848. doi:10.1021/jp053107n

\section{License and Terms}

This is an Open Access article under the terms of the Creative Commons Attribution License (http://creativecommons.org/licenses/by/4.0), which permits unrestricted use, distribution, and reproduction in any medium, provided the original work is properly cited.

The license is subject to the Beilstein Journal of Nanotechnology terms and conditions: (http://www.beilstein-journals.org/bjnano)

The definitive version of this article is the electronic one which can be found at: doi:10.3762/bjnano.8.262 